\title{
New host and distribution records of Pelecitus fulicaeatrae (Diesing, 1861) (Nematoda, Onchocercidae)
}

\author{
Graciela Escudero ${ }^{*}$, Julia I. Diaz ${ }^{2}$ and Juliana Notarnicola ${ }^{2}$ \\ ${ }^{1}$ Centro Nacional Patagónico (CENPAT), Boulevard Brown 2825, 9120 Puerto Madryn; \\ ${ }^{2}$ Centro de Estudios Parasitológicos y de Vectores (CEPAVE), Calle $2 \mathrm{~N}^{\circ}$ 584, 1900 La Plata; Argentina
}

\begin{abstract}
The nematode Pelecitus fulicaeatrae (Diesing, 1861) (Onchocercidae. Dirofilariinae) was found in the leg of a silvery grebe Podiceps occipitalis (Garnot. 1826) (Aves. Podicipediformes) at Puerto Madryn. Argentina. The specimens redescribed in this note are based on 7 females and 3 males. This is the first Argentinean record for this species and the second for South America, and represents the southern-most record of a species from this genus.
\end{abstract}

\section{Keywords}

Nematoda, Onchocercidae, Pelecitus, Podicipedidae, southwest Atlantic coast. Argentina

Species of the nematode genus Pelecitus (Railliet et Henry. 1910 ) are parasites found on at least 30 families of birds and three species of mammals. and are widely distributed all over the world (Bartlett 1983. Bartlett and Greiner 1986, JimenezRuiz et al.2004). Adult worms occur in nodules on the leg and foot of their hosts, while the microfilariae inhabit the host's feathered skin (Bartlett and Greiner 1986. Bartlett 1992). Here we report on a series of specimens of Pelecitus fulicaeatrae (Diesing. 1861) collected from a silvery grebe Podiceps occipitalis (Garnot. 1826) (Aves. Podicipediformes) found near Puerto Madryn. Argentina. P. fulicaeatrae was previously reported from birds in several families, such as Podicipedidae, Ardeidae. Anatidae, Accipitridae, Pandionidae, Rallidae. Laridae, and Coraciidae from Britain, Germany, USSR. Japan. France. Canada and Madagascar (Vanderburgh et al. 1984. Bartlett and Greiner 1986. Bartlett and Anderson 1987). In South America, there are only a few reports of this species: one from the gray-necked wood-rail Aramides cajanea (Statius Muller, 1776) (Rallidae) and one from jabiru Jabiru mycteria (Lichtenstein. 1819) (Ciconiidae) from northern Brazil (Pinto and Noronha 2003). Additionally, P. tercostatus (Molin. 1860) was recovered from a scaly-headed parrot Pionus maximiliani (Kuhl. 1820) (Psittaciformes) from San Antonio. Misiones, Argentina (Schuurmans Sterkhoven 1951).

Three males and 7 females of $P$. fulicaeatrae were collected from one nodule of the tibiotarso-tarsometatarsus articula-
Table I. Measurements of Pelecitus fulicaeatrae from Podiceps occipitalis in Argentina and those given by Bartlett and Greiner (1986) (mean followed by range in parentheses)

\begin{tabular}{lcc}
\hline References & $\begin{array}{c}\text { Bartlett and Greiner } \\
(1986)\end{array}$ & Present paper \\
Host & several & P. occipitalis \\
Localities & several & Chubut, Argentina \\
\hline Females (n) & 5 & 7 \\
Total length (in mm) & $20-26$ & $19.3(17.4-20.8)$ \\
Width at vulva level & - & $305(280-350)$ \\
Maximum width & $440-640$ & $642(559-728)$ \\
Oesophagus & $500-640$ & $539(500-610)$ \\
Vulva (dae) & $510-800$ & $533(400-650)$ \\
Nerve ring (dae) & $130-150$ & 200 \\
Tail & $40-90$ & $53(40-60)$ \\
Microfilariae (n) & & 10 \\
Length & - & $85(81-92)$ \\
Width & - & $7(7-8)$ \\
Males (n) & 3 & 3 \\
Total length (in mm) & $7-10$ & $9.9(8.9-10.5)$ \\
Maximum width & $225-300$ & $418(400-437)$ \\
Oesophagus & $425-510$ & $557(520-600)$ \\
Excretory pore (dae) & - & 105 \\
Nerve ring (dae) & $100-125$ & $133(125-150)$ \\
Tail & $40-50$ & $55(50-60)$ \\
Right spicule & 70 & $(56-68)$ \\
Left spicule & 80 & $89-100)$ \\
\hline
\end{tabular}

For explanation: dae - distance from anterior end. 

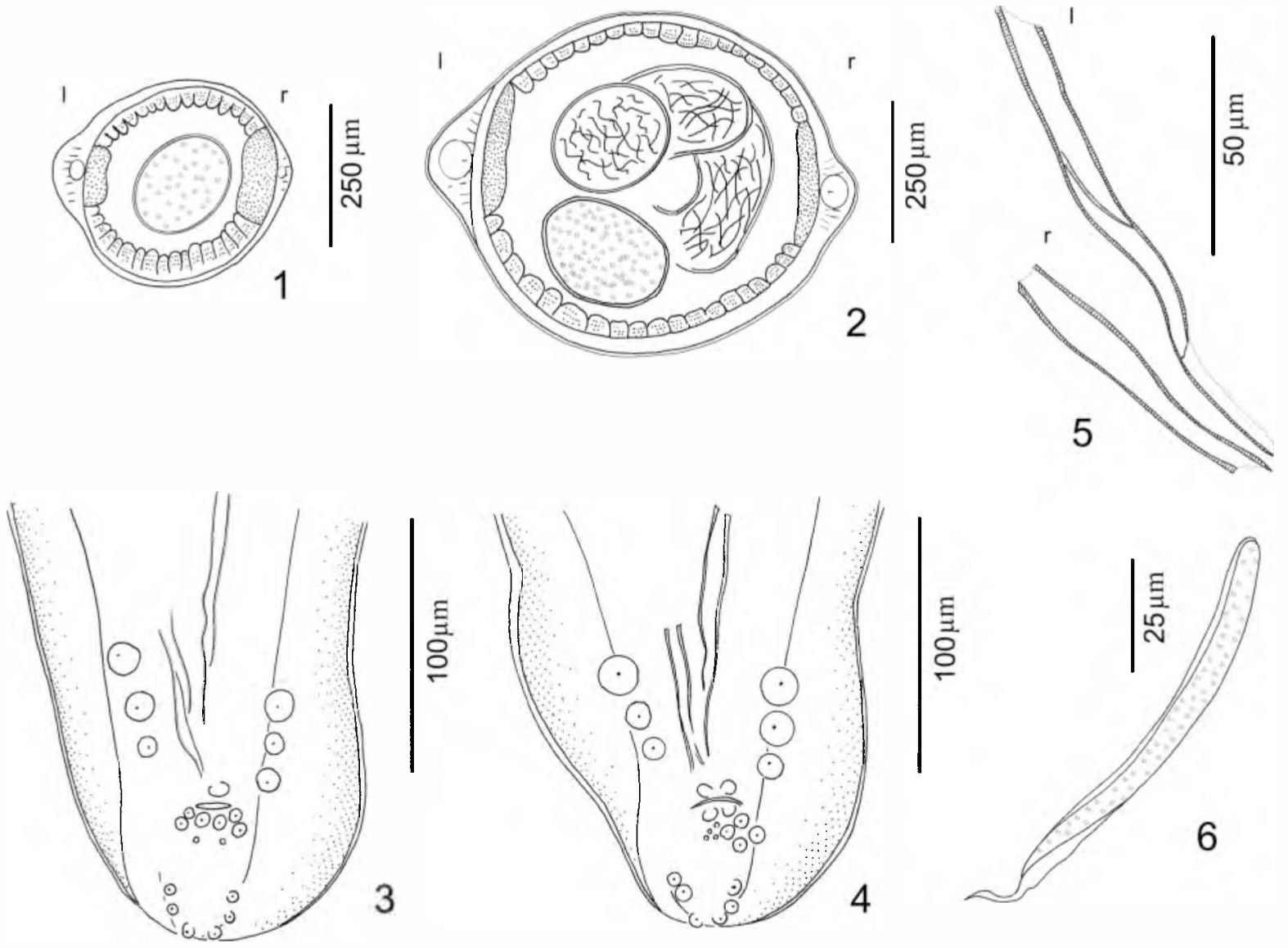

Figs 1-6. Adults of Pelecitus fulicaeatrae from Podiceps occipitalis: 1. Male, cross-section at midbody. 2. Female, cross-section at midbody. 3 and 4. Male, posterior end showing papillae arrangement. 5. Right and left spicules. 6. Microfilaria. Abbreviations: $r-$ right, $1-$ left

tion of a silvery grebe. The bird was found dead on a beach near Puerto Madryn $\left(42^{\circ} \mathrm{S}, 65^{\circ} \mathrm{W}\right)$, Chubut, Argentina, in June 2005. The host species, widely distributed in South America, does not undertake a long distance migration. The specimens were removed from the leg, fixed in $10 \%$ formalin, stored in $70 \%$ ethanol, and cleared in lactophenol for light microscope study. One male and 1 female were dried using the critical point method, and examined by SEM (Jeol JSV $6063 \mathrm{LV}^{\circledR}$ ). We follow the terminology given by Bartlett and Greiner (1986). Voucher specimens were deposited in the Helminthological Collection of the Museo de La Plata (CHMLP), La Plata, Argentina ( $\mathrm{N}^{\circ}$ 5702). Measurements are given in micrometres, unless otherwise stated.

Measurements for both males and females are presented in Table I. The body of the filarioids is regularly twisted, with asymmetrical lateral alae (Figs 1 and 2). From an apical view, the papillae form a square with 4 inner-labial and 4 outercephalic papillae; the amphids are not salient (Fig. 7). The oesophagus is stout, cylindrical, muscular, and clearly demarcated from the intestine.

The body of the males is shaped as a loose dextral spiral or helix, with 4-5 rotations; the outer diameter of the rotation is 185 long. Width of the left lateral ala at midbody is 50 (from one specimen) (Fig. 1). The caudal ala asymmetrical, left side larger than right side. Caudal papillae distributed as follow (Figs 3 and 4): (i) 3 pairs of large, pedunculate preanal papillae extending into alae, symmetrical in arrangement; (ii) 2 pairs of smaller, sessile to semipedunculate postanal papillae, irregularly placed, near the group iv; (iii) 3 pairs of small, sessile papillae in the caudal extremity, symmetrical or asymmetrically arrangement, occasionally forming a circle; (iv) small, sessile perianal papillae, one pair anterior (or single papilla), one pair posterior to anus, plus small papillae below them. Hyaline inclusions not present within caudal alae (Figs 3 and 4). Spicules delicate, unequal, and dissimilar (Fig. 5). Postdeirids slightly visible, with 498 from posterior end (from one specimen).

The body of the females is shaped as a loose to medium tight helix, 4-5 rotations present, the outer diameter of the helix 850. Width of left lateral ala at midbody 100 (from one specimen) (Fig. 2). Vulva at the level of the oesophagic-intestinal junction. Postdeirids slightly visible located $2.2-2.5 \mathrm{~mm}$ from posterior end (from one specimen). Caudal end rounded. Phasmids prominent and subterminal in position (Fig. 8). Microfilariae sheathed; anterior extremity rounded; caudal extremity tapered (Fig 6). 

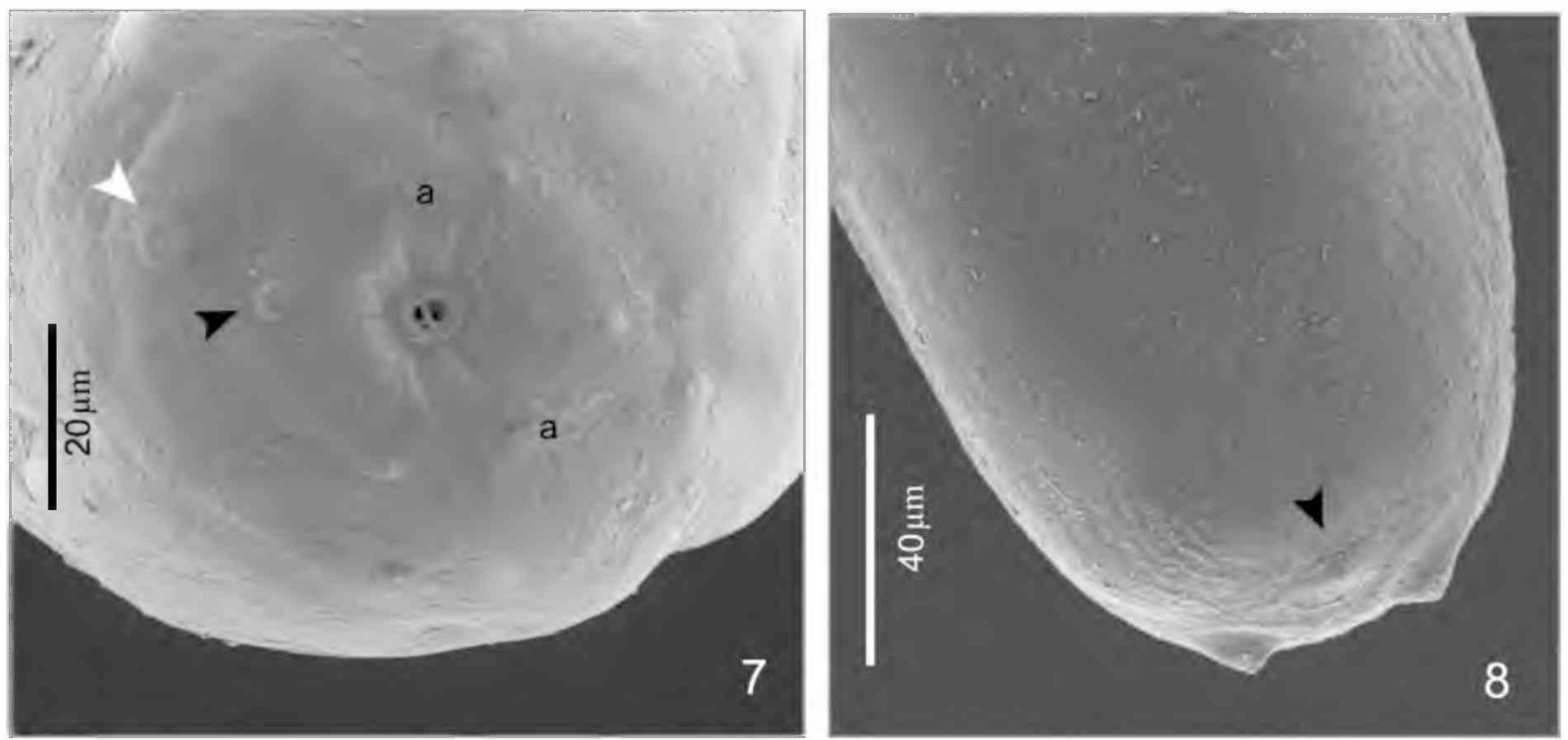

Figs 7 and 8. Pelicitus fulicaeatrae: 7. Apical view, showing cephalic papillae arrangement (see arrows) and amphids (a). 8. Female, posterior end showing the anus (arrow) and prominent phasmids

The general morphology and measurements of these specimens agree with those given by other authors (Vanderburgh et al. 1984. Bartlett and Greiner 1986). In males the position and number of the caudal papillae was variable. Two out of the three males studied here exhibited the group of papillae displaced to the left side, while in the third male this group was symmetrically placed. In addition. in group (iv), the precloacal papillae were either single or double (Figs 3 and 4). These observations are in accordance with the intraspecific variation mentioned by Bartlett and Greiner (1986) for $P$. fulicaeatrae and other species in Pelecitus. Bartlett and Greiner (1986) reported symmetrical alae for the females. In contrast. we observed that the females have asymmetrical lateral alae, the left ala being larger than the right, as was stated for the males.

The present finding extends the range of P. fiticaeatrae and represents the southern-most record of a species of this genus. Moreover, this is only the second time that a species of Pelecitus has been registered in Argentina.

Acknowledgements. The authors gratefully thank the staff of the Servicio de Microscopía Electrónica de Barrido, Museo de La Plata, for their technical assistance, Pim Edelaar for help in the field, and Nathan Senner for improving the English of the manuscript. GE is member of Agencia Nacional de Investigaciones Científicas y Técnicas (ANPCyT). JD and JN are members of Consejo Nacional de Investigaciones Científicas y Técnicas (CONICET). This study was funded by ANPCyT (PICT 11-902) and CONICET (PIP 5356).

\section{References}

Bartlett C.M. 1983. Zoogeography and taxonomy of Dirofilaria scapiceps (Leidy, 1886) and D. uniformis Price, 1957 (Nematoda: Filarioidea) of lagomorphs in North America. Canadian Journal of Zoology, 61, 1011-1022.
Bartlett C.M. 1992. Cold-hardiness in Pelecitus fulicaeatrae (Nematoda: Filarioidea), a parasite of the ankles of Fulica americana (Aves). Journal of Parasitology, 78, 138-139. DOI: $10.2307 / 3283700$

Bartlett C.M., Greiner E.C. 1986. A revision of Pelecitus Railliet \& Henry, 1910 (Filarioidea, Dirofilariinae) and evidence for the "capture" by mammals of filarioids from birds. Bulletin $d u$ Muséum National d'Histoire Naturelles Paris, Sect. A, 8, 47-99.

Bartlett C.M., Anderson R.C. 1987. Pelecitus fulicaeatrae (Nematoda: Filarioidea) of coots (Gruiformes) and grebes (Podicipediformes): skin-inhabiting microfilariae and development in Mallophaga. Canadian Journal of Zoology, 65, 2803 2812.

Jimenez-Ruiz F.A., Gardner S.L., Cervantes F.A., Lorenzo C. 2004. A new species of Pelecitus (Filarioidea: Onchocercidae) from the endangered tehuantepec jackrabbit Lepus flavigularis. Journal of Parasitology, 90, 803-807. DOI: 10.1645/GE213R1

Pinto R.M., Noronha D. 2003. Analysis of Brazilian species of Pelecitus Railliet \& Henry (Nematoda, Filarioidea) with establishment of new records. Revista Brasileira de Zoologia, $20,361-364$.

Schuurmans Sterkhoven J.H. 1951. Nematodos parasitarios de anfibios, pajaros y mamiferos de la Republica Argentina. Acta Zoologica Lilloana, 10, 315-400.

Vanderburgh D.J., Anderson R.A., Stock T.M. 1984. Pelecitus tubercauda n. sp. (Nematoda: Filarioidea) from Geothylis trichas $\mathrm{L}$. and a redescription of $P$. fulicaeatrae (Diesing. 1861) LópezNeira, 1956. Canadian Journal of Zoology, 61, 362-367. 